OPEN ACCESS

Approved by:

Frontiers Editorial Office,

Frontiers Media SA, Switzerland

*Correspondence:

Thomas P. White

thomas.1.white@kcl.ac.uk

†These authors have contributed equally to this work

Specialty section: This article was submitted to

Brain Imaging and Stimulation, a section of the journal

Frontiers in Human Neuroscience

Received: 13 August 2019 Accepted: 19 September 2019

Published: 09 October 2019

Citation:

White TP, Gilleen J and Shergill SS (2019) Corrigendum: Dysregulated but

not decreased salience network activity in schizophrenia.

Front. Hum. Neurosci. 13:346

doi: 10.3389/fnhum.2019.00346

\section{Corrigendum: Dysregulated but not decreased salience network activity in schizophrenia}

\author{
Thomas P. White ${ }^{\star \dagger}$, James Gilleen ${ }^{\dagger}$ and Sukhwinder S. Shergill \\ Department of Psychosis Studies, Institute of Psychiatry, King's College London, London, United Kingdom
}

Keywords: schizophrenia, salience, cortical networks, fMRI, reward

\section{A Corrigendum on}

Dysregulated but not decreased salience network activity in schizophrenia

by White, T. P., Gilleen, J., and Shergill, S. S. (2013). Front. Hum. Neurosci. 7:65. doi: 10.3389/fnhum.2013.00065

In the original article, we neglected to include the funder "European Research Council ERC Consolidator Grant \#311686" and the "NIHR Mental Health Biomedical Research Centre at the SLaM NHS Trust and King's College London" to SS.

A Funding statement has therefore been added to the published article:

"Funding was provided by the European Research Council ERC Consolidator Grant, \#311686 and the NIHR Mental Health Biomedical Research Centre at the SLaM NHS Trust and King's College London, to SS."

The authors apologize for this error and state that this does not change the scientific conclusions of the article in any way. The original article has been updated.

Copyright (C) 2019 White, Gilleen and Shergill. This is an open-access article distributed under the terms of the Creative Commons Attribution License (CC BY). The use, distribution or reproduction in other forums is permitted, provided the original author(s) and the copyright owner(s) are credited and that the original publication in this journal is cited, in accordance with accepted academic practice. No use, distribution or reproduction is permitted which does not comply with these terms. 